\title{
Business Systems Theory and Employment Relations
}

DOI:

10.1093/oxfordhb/9780199695096.013.005

Link to publication record in Manchester Research Explorer

\section{Citation for published version (APA):}

Allen, M. M. C., Wilkinson, A. (Ed.), Wood, G. (Ed.), \& Deeg, R. (Ed.) (2014). Business Systems Theory and Employment Relations. In A. Wilkinson, G. Wood, \& R. Deeg (Eds.), The Oxford Handbook of Employment Relations: Comparative Employment Systems (pp. 86-113). (Oxford Handbooks ). Oxford University Press. https://doi.org/10.1093/oxfordhb/9780199695096.013.005

Published in:

The Oxford Handbook of Employment Relations

\section{Citing this paper}

Please note that where the full-text provided on Manchester Research Explorer is the Author Accepted Manuscript or Proof version this may differ from the final Published version. If citing, it is advised that you check and use the publisher's definitive version.

\section{General rights}

Copyright and moral rights for the publications made accessible in the Research Explorer are retained by the authors and/or other copyright owners and it is a condition of accessing publications that users recognise and abide by the legal requirements associated with these rights.

\section{Takedown policy}

If you believe that this document breaches copyright please refer to the University of Manchester's Takedown Procedures [http://man.ac.uk/04Y6Bo] or contact uml.scholarlycommunications@manchester.ac.uk providing relevant details, so we can investigate your claim.

\section{OPEN ACCESS}




\section{Business Systems Theory and Employment Relations}

Matthew M. C. Allen

Pre-publication version of:

Allen, M.M.C. (2014), 'Business Systems Theory and Employment Relations', in A. Wilkinson, G. Wood and R. Deeg (eds), The Oxford Handbook of Employment Relations, Oxford: Oxford University Press, pp. 86-113.

\section{Introduction}

In the wake of the increasing internationalization of product, capital, and some labour markets, understanding the ways in which companies in different locations create and sustain competitive advantages has become ever more important for policy makers, company managers, union officials, entrepreneurs, and employees. The 'business systems' framework represents a highly influential contribution in this area. It seeks to explain the links between institutionalized systems of economic co-ordination and control, on the one hand, and firms' routines, organizational capabilities and competitiveness, on the other. The framework has been most closely associated, but not exclusively so, with various publications by Richard Whitley (1990, 1992a, 1992b, 1994, 1999, 2000, 2003, 2005, 2007, 2010). Whilst the business systems framework shares some common ground with the Varieties of Capitalism (VoC) paradigm, it differs in significant ways.

This contribution is structured as follows. The next section sets out the business systems framework. The distinctions between it and the VoC approach are, then, examined, and important developments in the framework are identified and discussed. Subsequent sections examine individual business systems in detail. The growing importance of internationalization to business systems, in general, and multinational companies, in particular, is discussed. Finally, conclusions are drawn and suggestions about the possible 
future development of the framework are put forward. This contribution focuses on issues relating to employment relations (for a related review, see Wilkinson and Wood, 2012); however, it should not be forgotten that other aspects of the business systems framework, such as ownership and control structures, corporate governance, the role of political authorities, public science systems, and inter-firm networks, are likely to be important influences on the ability of companies to pursue successfully certain employment strategies. It is also worth noting at the outset that, although the term 'business systems' has often been prefaced by the adjective 'national', it is not necessarily the case that the country level is the most pertinent unit of analysis for the study of organizations and, indeed, business systems, as more than one business system may exist within one country (Allen and Whitley, 2012; Morgan, 2007a, 2007b; Whitley, 2007, 2009; see also Wood et al., 2009).

\section{The 'Business Systems’ Framework}

The cardinal contention behind the business systems framework is that the institutionalized rules of the game - both formal and informal ones - constitute and shape the types of firms that exist, their priorities, the interconnections between them, and, consequently, the kinds of routines, organizational capabilities, and strategies that they can implement successfully (Whitley 1999, 2007, 2010). As a result, companies are likely to be more successful in some sub-sectors than others, as, firstly, the types of market, technological, managerial and organizational challenges that firms will encounter will vary from sub-sector to sub-sector, and, secondly, the ability of companies to surmount those challenges will be shaped by their institutional setting (Allen and Whitley, 2012; Casper and Whitley, 2004; Whitley, 2007: 147). In order to show these links more concretely, with an especial emphasis on employment relations, it will be necessary to examine 'business systems' and the characteristics of subsectoral competitiveness and innovation in more detail. 
Business systems can be defined as the distinctive and dominant (or usual) ways in which economic activities are co-ordinated and controlled within a given territory that is governed by particular kinds of institutions. Those involved in that process can cover owners, managers, employees, experts, state representatives, and unions. The ways in which those groups interact will, importantly, reflect the extent to, and means by, which economic activities are authoritatively co-ordinated and controlled. That authority could be exercised through organizational hierarchies, contracts, informal commitments or personal ties (Whitley, 1999: 33). Therefore, in order to understand the different types of business systems, and the key ways in which they vary, it is first necessary to examine the institutions that structure them. The key institutional systems underpinning business systems are: the state, the financial system, the skill development and control system, and norms governing trust and authority relationships.

The state can influence business-system characteristics by stipulating the conditions under which firms can be incorporated; by regulating which organizations can or cannot operate in certain markets; by determining bankruptcy rules; by encouraging or discouraging the presence and importance of intermediary bodies, such as employers' associations and unions; and by intervening directly in the economy by sharing investment costs and risks with companies. Together these factors shape product, capital and labour markets in terms of their segmentation, competitive rivalry, resource mobility, and firm flexibility (Whitley, 1999: 49). In other words, the state can, amongst other things, influence the degree to which firms compete or co-operate with one another; the ability of unions to play a role in skill formation systems, and wage bargaining; the availability of funds; and the willingness of firms to undertake investments in risky technological innovations. 
The financial system, too, has various aspects; however, a crucial distinction is drawn in the area of corporate financing. In particular, the relative importance within economies of capital markets or banks in funding companies provides a key means to differentiate business systems. If capital is provided through equity markets by institutional investors, such as pension funds and unit trusts, the users of capital are likely to be relatively remote from shareholders. This is especially so if a market for corporate control exists; that is, if firms can be acquired relatively easily. By contrast, if capital is provided by banks, which act as intermediaries between savers and companies, then direct links between firms and lenders are likely to be established. Consequently, banks may become locked into the commercial futures of the firms that they have lent to. Although this dichotomy between business systems is not as distinct in practice, both within territories and over time, as it is in theory (Goyer, 2006, 2011; Tylecote and Ramirez, 2006), it forms a useful basis on which to classify countries and many of the companies within them. The reason for this is that the ownership and control of firms have significant implications for their ability, firstly, to invest for the long term, and, secondly, to forge obligational long-term, trust-based relationships with, for example, suppliers, and employees. This, in turn, has ramifications for the types of capabilities that firms are able to develop, and their ability to become competitive in certain sectors (Whitley, 1999: 49-50; Whitley, 2007).

The skill development and control system covers, firstly, the education and training system, and, secondly, important aspects of labour markets. These two elements can, in turn, be disaggregated further. For instance, from a business-systems perspective, there are two highly important features of the education and training system: firstly, the extent to which employers, state agencies, and unions collaborate to determine the content of training 
programmes, and to certify skills; and, second, the degree to which practical training within firms is complemented by theory-based courses within educational establishments. In terms of labour markets, the critical elements are, firstly, the involvement of unions and professional associations in the provision of skills; secondly, the degree to which unions and professional associations are organized according to expertise, the enterprise, the sector, or the country; and, finally, the extent to which wage bargaining is centralized. These factors influence the mobility of workers between firms (and between sectors), organizational career structures, and collaboration not only between employers and employees, but also between different firms. This, once again, has implications for the type of activities that firms will be able to carry out competently, and their subsequent ability to compete successfully in certain product markets (Whitley, 1999, 2007).

Inter-firm co-operation is also influenced by the norms and values governing trust and authority relations. Trust in formal rules, regulations, and the agencies that enforce legislation, and contractual agreements has important implications for the governance of economic activities, and, hence, the types of firms that emerge as well as the capabilities that they are likely to have (Whitely, 1999, 2007). For instance, if investors do not trust the relevant agencies to enforce legislation and commercial agreements, they are unlikely to delegate any authority or decision-making powers to those to whom they do not have strong family or personal ties. Consequently, firms may well be small, and alliances between firms very difficult to forge. If trust is high, however, owners are more likely to share authority with some employees and business partners. As a result, large firms with, at least for some employees, career structures are likely to emerge. Thus, under contrasting levels of trust in formal rules and legal agencies, different types of firm are likely to become more common; 
their priorities will vary, as will their capabilities, and ability to compete successfully in different markets.

It is important to note that it is not just the individual elements that contribute to the characteristics of business systems, but also their interdependencies or complementarities (Whitley, 1999: 53-54; see also Crouch et al., 2005). For instance, the ability of firms to adopt a long-term perspective on investment decisions, and employment relations, inter alia, can be promoted by owners, such as families with a controlling stake or banks, who are committed to the business. In terms of employment relations, such a long-term perspective is likely to complemented - or reinforced - if other institutions also exert a similar influence. For example, labour-market institutions that grant employee representatives a say in strategy decisions or the organization of work within establishments are likely to restrain company's abilities to decrease the size of the workforce or to change the activities that are carried out by workers rapidly. This can encourage employers yet further to adopt a long-term approach to employees. Consequently, the mutual commitment between employers and employees is likely to increase; this, in turn, may then enable the company to encourage employees to invest in firm-specific skills that can aid competitiveness in certain sectors.

Although in discussions of business systems, Whitley $(1999,2007)$ has linked particular types to countries or regions within countries, the business systems framework is, arguably, best treated a collection of ideal types in the Weberian sense (Morgan, 2007a). In other words, Whitley $(1999,2007)$ does not claim that the different business systems capture and reflect the complexities of countries or regions as they exist in reality. Therefore, the business systems framework should not be assessed on the extent to which any particular business system corresponds completely to any country or region. Similarly, the framework did not, 
initially, seek to provide a detailed analytical tool to assess the dynamics of capitalist systems.

Rather, Whitley claims that the types of business systems that he put forwards are logically consistent abstractions of socio-economic phenomena. Two important corollaries follow from this claim. Firstly, the discussion of business systems is limited to those that will not be undermined by logical inconsistencies (Whitley, 1999: 41; 2007: 11-12; $c f$. Wood and Frynas, 2006). For instance, in one sense, it is, given the number of institutional domains that Whitley identifies as being important, possible that numerous business systems could exist even if those domains are treated in just a dichotomous way. However, many of these would suffer from severe tensions between particular institutional domains. For instance, finding a business system that combines a developmental state with strong unions and business associations that can pursue strategies that are independent of those of the state will be unlikely. Similarly, large vertically integrated firms are unlikely to form long-term alliances with other firms, as such companies will be able to draw on internally generated complementary assets and capabilities. In short, the theoretical business system associated with an empirically implausible firm type is not considered in the framework.

The second corollary relates to the analytical use of the framework. Arguably, the business systems approach should be used not just to identify the ways in which existing countries or locations do or do not conform to one or other business system (which forms part of the analysis by, for instance, Morgan and Kubo, 2005; Schneiberg, 2007), but also to examine ways in which firms, regions and countries do not conform to the posited, logically consistent ideal types (Morgan, 2007a). This can, for instance, involve an analysis of the conditions under which firms can draw on international resources to overcome institutional deficiencies 
to be competitive in particular industries (Allen and Whitely, 2012). Alternatively, it could cover a close examination of the ways in which firms and other actors are able to shape their local institutional settings in ways that do not necessarily adhere closely to the ideal type, but that are designed to enhance competitiveness (Becker-Ritterspach et al., 2010; Casper and Whitley, 2004; Crouch et al., 2009).

\section{Differences to the 'Varieties of Capitalism' Framework, and Developments within the}

\section{Business Systems Framework}

The key difference between the business-systems framework and the VoC paradigm lies, arguably, in the analytical focus that is placed on the firm. Despite claims to the contrary, the VoC paradigm places relatively little emphasis on the firm as a separately constituted collective actor that has varying autonomy (Allen, 2004; Crouch 2005; $c f$. Hancké, Rhodes and Thatcher, 2007). Indeed, it could be argued that, within the VoC perspective it is not necessary to examine the specific managerial and organizational challenges that firms face, because the strategic objectives and associated organizational routines can be understood by analysing the national institutional setting of companies (Allen, 2004). In other words, firms within any one country are, within the VoC framework, construed as being homogeneous. This is not the case in the business systems approach.

Although it will not be possible to go into details here, the business-systems framework builds on contentions from the literature on the resource-based view of the firm (Whitley, 2007: 147-148; Whitley, 2010), and the 'sectoral systems of innovation' approach (Casper and Whitley, 2004; Whitley, 2007: 204-206). For instance, with the former, the businesssystems perspective shares an emphasis on explaining the detailed ways in which firms and the managers within them create collective competitive competencies (Dosi et al., 2000; 
Penrose, 1959; Teece et al., 1997). This focuses the analysis on the activities and core tasks that are carried out within firms, the routines that are used to create and develop core competencies, the interdependencies between those various activities and routines, and the ways in which those interdependencies are managed. This approach can be contrasted to those that place greater emphasis on factors outside the firm in their analyses. For instance, transaction cost economics emphasizes the advantages or disadvantages associated with using the market or the firm - that is, hierarchically ordered processes within an organization - to perform economic activities. It highlights the costs that firms incur, if they use the market, to search for appropriate suppliers/customers, to draw up contracts, to monitor performance, and to enforce those agreements, if the other company fails to deliver the product or service in the right quantity or quality (Williamson, 1985). Similarly, some strategy frameworks, such as Porter's (1979) five forces model focus on factors that are outside the company to help firms devise appropriate responses.

In common with the 'sectoral systems of innovation' approach, the business-systems approach seeks to anticipate the managerial and organizational challenges that firms are likely to face given the technological, knowledge, and competition characteristics within any firm's sub-sector (Malerba, 2002; Malerba and Orsenigo, 1997). The ability to overcome these challenges will depend upon the establishment and development of a set of appropriate routines and capabilities. For instance, in firms that are attempting to overcome technological and market risks to develop radically new technologies, managers must be able to encourage employees to invest in skills that could become redundant if the firm were to fail. In other words, managers must be able to overcome the challenges associated with competence destruction. This can be done by offering employees relatively large stakes in the organization or by offering them substantial bonuses if the firm succeeds. By contrast, in 
firms in which employees face lower competence destruction risks, managers may need to encourage employees to invest in firm-specific skills that, by definition, are either of no value or cannot easily be sold to other employers. This challenge may be met by making credible commitments to them in the form of employment guarantees that are supported by strong legal rights for employee representatives (Casper and Whitley, 2004).

Yet, the business-systems framework is distinct from the resource-based view of the firm and the sectoral systems of innovation' perspectives: it stresses the importance of the interdependencies between firms' abilities to compete successfully by overcoming key organizational challenges through the creation and development of routines and capabilities, on the one hand, and the external institutional setting of firms, on the other (Casper and Whitley, 2004; Whitley, 2007). For example, the ability of employers to make credible commitments to employees about their employment, and the use of their skills will be influenced by the presence of works councils, whose existence and powers do not depend upon employers, but on legislation, to monitor managers' behaviour (Croucher et al., forthcoming; Harcourt and Wood, 2007; Whitley, 1999). It is these links that recent research has analysed (Allen and Whitley, 2012; Casper, 2007; Crouch and Voelzkow, 2009; Schneiberg, 2007; Sako and Jackson, 2006; Wilkinson and Fay, 2011).

A number of corollaries follow from this analytical focus. Firstly, the specific institutional settings of firms become part of the research, as these cannot be inferred directly from the national or macro-level framework (Allen, 2004; Allen et al., 2011; Casper and Whitley, 2004; Morgan and Kubo, 2005). Indeed, the particular institutional settings of firms can be shaped by the increasing internationalization of product, capital and some labour markets (Allen and Whitley, 2012; Almond, 2011; Casper, 2009; Lange, 2009), so that it is not just 
the national institutional framework of the country that the firm is located in that is important, but those abroad, potentially, as well. Secondly, and consequently, this highlights the ways in which specific institutional settings may contain elements or resources that diverge from the archetypal institutional regimes (Lane and Wood, 2012; Schneiberg, 2007; Wood et al., 2009). Thirdly, it draws attention to the role of actors in shaping institutions, and, hence, how institutions may become the subject of contestation (Becker-Ritterspach et al., 2010; Crouch and Voelzkow, 2009; Djelic and Quack, 2003; Morgan, 2007b; Streeck, 2009; Whitley, 2007). Finally, as the primary unit of analysis within much of the recent business-systems literature is the firm or the industry level rather than the national institutional setting, the approach, arguably, opens up a richer depiction of firms and the challenges that they face compared to the portrayal of firms in the VoC perspective (Casper and Whitley, 2004; Morgan, 2007a).

Where the business systems literature may be lacking in comparison to the VoC approach is in the systematic application of the analytical framework to countries beyond Japan and those in Western Europe and North America. Although the business systems framework has been used to analyse the development of economies in Central and Eastern Europe (Czaban et al., 2003; Whitley and Czaban, 1998), recent research in this area has tended to draw on the VoC paradigm (see, for instance, Allen and Aldred, 2011; Bohle and Greskovits, 2007; Lane and Myant, 2007; Nölke and Vliegenthart, 2009). Only a limited number of studies, therefore, has attempted to apply and extend the business systems framework systematically to other countries and regions (Wood and Frynas, 2006; Wood et al., 2011).

\section{Employment Relations within Business Systems}


This contribution sets out five ideal types of business systems, and discusses the evidence on the links between employment relations and firm capabilities that can be interpreted from a business-systems perspective; that is, evidence that, in general, combines an analysis of firms' employment strategies, organizational objectives, and institutional setting. To be sure, not all of the research reviewed here has been conducted explicitly within a business-systems approach; it can, however, contribute to that strand of the literature. As noted above, the socio-economic reality of firms should not be expected to conform completely to any ideal type of business system. Table 1 summarizes the key characteristics of those five ideal firm types that are discussed here, the associated business system, the anticipated employment relations within the firms, and their organizational capabilities.

XXX

Table 1 about here

XXXX

\section{Fragmented}

Fragmented business systems develop in environments that are characterized by low levels of trust and by unreliable formal institutions (Whitley, 1999: 59). In other words, the rule of law is very limited or non-existent. Consequently, this makes predicting the outcomes of any legal process exceedingly difficult. The limited applicability of the rule of law is likely to reflect either a weak or a predatory state. As a result of these characteristics, commercial risks will be difficult to share. This, in turn, will mean that firms are likely to be small, be independent of political elites ( $c f$. the situation in China and South Korea) and rely on their own, limited resources and capabilities to be competitive. These capabilities are likely, because of the low-trust and weak legal environment within which firms operate, to be 
confined to the owner-manager's competencies. Where links to other companies exist, these are likely to be based upon familial or strong personal ties. Similarly, within companies, owner-managers will be reluctant to share any authority with employees, and employees will, because they do not have the opportunity to develop any substantive skills, not represent a constraint on the firm's decision making. Finally, the generally low skill levels of employees within opportunistic firms as well as the dearth of opportunities for workers to develop new skills will mean that employees do not have prolonged or diverse careers in opportunistic firms.

The capabilities that such firms are likely to develop will be restricted to those of the ownermanager. Thus, opportunistic firms will only be able to co-ordinate economic activities that are within the purview of the owner-manager. The range of that co-ordination may be extended by familial or strong personal ties, but it is still likely to be limited in scope. As a consequence, most employees in opportunistic firms do not have any real discretion or ability to develop their skills, organization learning will be limited, and the propensity of the firm to acquire new capabilities will depend upon the learning of the owner-manager or a very small number of trusted managers within the firm. However, because opportunistic firms are not constrained by any employees, they will, theoretically, be able to reconfigure their capabilities quickly if they operate in markets that enable or require them to do so. In practice, of course, if the owner-manager does not possess the requisite skills both to adapt the business and to make it a success in the changed environment, the company will fail.

The informal economy in Nigeria matches many of these characteristics (Fajana, 2008; see also Wood and Frynas, 2006 and Wood et al., 2011 for related studies). For instance, although employment in the informal economy in Nigeria is estimated to account for 50 per 
cent or more of total employment, most of the enterprises in the sector are small in terms of the number of employees. In addition, such enterprises often form and then disband relatively rapidly. The formation of enterprises frequently depends upon the acquisition of new skills by the owner-manager or a small amount of capital from family or friends. Owner-managers often pay their employees relatively low wages, invest little in the development of their employees' skills, and do not countenance unions within their workplaces. The capabilities that such firms possess are restricted to the owner-manager's skills and knowledge. The survival of the enterprise, therefore, depends upon that of the owner-manager or the ownermanager continuing to take an active interest in the business or the owner-manager possessing the skills to adapt the enterprise to a changed business environment (Fajana, 2008).

\section{Specialized Network}

Specialized networks can be distinguished between two distinctive ideal types of business system (co-ordinated industrial districts and project networks). The variation within the actual forms that adhere relatively closely to those ideal types can be quite great. Despite this, these various network forms share certain characteristics that can be used to distinguish them from other types of firms. The most pertinent distinguishing features are the typical ownership and control patterns of firms within the network, and their employment relations. These result in distinctive capabilities.

In terms of ownership, many firms within specialized networks are owned and controlled either directly by the company's founders (or their heirs) or via the stock market by institutional investors. Most firms within such networks tend to be relatively small. Within both types of specialized networks, firms are constrained to a considerable degree by 
employees, as it is they who have the crucial skills and knowledge that form the foundations of the firm's competitiveness. A corollary of this is that companies must also share a considerable amount of authority with their employees across a relatively wide range of issues. However, the longevity of organizational careers is likely to be limited in for many employees in specialized networks. For those in co-ordinated districts, this is because workers may seek new employment to ensure that their skills are constantly up-graded; for those in project network, because the project has been completed or because the 'project', such as developing a new bio-technology-based therapeutic treatment or a novel piece of standard applications-based software, was unsuccessful. The scope of organizational careers is likely to be low, as employees with highly valued, specialized skills and knowledge will, ipso facto, lack the necessary experience and expertise to conduct other activities within the organization.

These characteristics are likely to result in firms that, because of their small size and specialization, will find it difficult to co-ordinate with a wide variety of other companies. This may be because firms fear the loss of key knowledge to potentially larger, more diversified competitors (Allen and Whitley, 2012) or because they lack the resources to coordinate economic activities beyond those who are similarly specialized. Such firms are also likely to have limited organizational learning capabilities, as it is the members of teams who have the expertise and who interact with one another. Consequently, learning may be embedded within teams rather than within the organization, sensu stricto. Whilst project networks that operate in fluid labour markets and in high-technology sectors are likely to be able to reconfigure their capabilities quickly, those specialized networks that resemble coordinated industrial districts are likely to have more limited reconfigurational capabilities, as 
a result of the slower pace of technological and knowledge evolution, and more stable labour markets (Whitley, 2010: 464).

Many of these characteristics can be observed in different countries and regions around the world. Denmark, for instance, has, alongside large companies that are often controlled by foundations, such as the A.P. Moller-Maersk Group, Carlsberg and Leo Pharma, numerous highly successful small companies. In these latter firms, founding families frequently maintain a controlling stake in the business (Kristensen, 2006: 298). In Germany, many of the country's Mittelstand or small and medium-sized enterprises that are significant exporters are family-owned and -controlled businesses (Simon, 2007: 330). Similarly, high-technology firms in their initial stages will be owned and controlled by the founding entrepreneur. Even when such firms grow, and stakes in the company are often sold initially to private-equity investors, those backers will often assume managerial responsibilities within the firm, and they could be construed as direct owners who exert control over the enterprise. Even when high-tech companies become large, as, for instance, Google has done, the company can be structured in a way that provides the founders and key personnel with a controlling stake in the firm.

In terms of authority sharing, Kristensen (2006: 301) has noted that for small manufacturing firms in Denmark to remain or become competitive, they must be attractive to highly skilled workers. In order to do this, firms seek to specialize in certain processes rather than perfecting a particular product. This reduces the chances that repetitive jobs are created within the company, as a push to become more efficient in delivering a particular product is likely to result in a desire to increase volumes and, hence, to standardize certain activities. For workers who are accustomed to conducting ever more challenging jobs, and who can 
readily access high-quality training courses, standardized, de-skilled jobs will not be attractive. As a result, they are likely to leave the company, and the firm may well lose its reputation and its competitiveness, as it will no longer be able to meet the requirements of sophisticated customers (Kristensen, 2006, 2011).

This clearly illustrates, firstly, the degree of authority sharing with employees, and, secondly, the ways in which firms in co-ordinated industrial districts are constrained by their employees, as the loss of key employees will have a detrimental effect on competitiveness. The scope of authority sharing in many Danish companies is also considerable, as hierarchies are often flat (Kristensen, 2006). Although it is possible for skilled workers to become supervisors, engineers and production managers within companies (Kristensen, 2006: 303), it would appear that this is unlikely to be achieved within the same company, as the Danish labour market is a highly fluid one (Croucher et al., forthcoming; Kristensen, 2006; Nielsen and Lundvall, 2006) that encourages workers to learn 'by moving around' (Lundvall and Lorenz, 2006: 426). This means that the longevity and scope of organizational careers are likely to be low, as suggested by the ideal typical 'specialized network'.

Although fluid labour markets and the limited length of organizational careers will mean that there is a high turnover of personnel within Danish firms, this will not lead to reconfigurational capabilities that enable companies to alter radically and rapidly their organizational competencies. As noted above, Danish firms often seek, firstly, to increase the depth of their specialization and, secondly, to apply their capabilities to new areas; consequently, the ability of such firms to depart from that specialization, and develop expertise in radically new areas is likely to be limited. 
A fluid labour market is also a characteristic of co-ordinated industrial districts in Italy. For instance, in the production of specialized machinery in Italy, it has been found that, due to a dearth of appropriately skilled employees, poaching is commonplace (Farrell and Holten, 2004). The companies that recruited workers are able to draw on the knowledge and skills of production methods if their new employees to up-grade their organization's capabilities; whilst this may have benefits for the sector as a whole, it may deter company investments in activities that cannot be patented (Farrell and Holten, 2004). The presence of poaching within the industry is one indication that competitors and potential competitors do not co-operate with one another. Thus, the ability to co-ordinate activities across the industry will be limited. Where co-ordination does take place, it occurs vertically within production chains, and horizontally between firms that provide complementary rather than competing goods (Farrell and Holten, 2004).

By contrast, specialized networks that more closely resemble professional project networks than they do co-ordinated industrial districts are more likely to have greater reconfigurational capabilities. Although this will be bounded by the variety of tasks that such networks are asked to carry out, the ability of professional project networks to recruit specialists in a range of areas, and then integrate them to ensure that the required activities are completed means that they will be more flexible - or, to put it a different way, will be capable of 'being reconfigured' in more diverse ways - than networks more commonly found in co-ordinated industrial districts that are built around key skills and organizational capabilities for a certain economic sector (Whitley, 2007; see also Morgan and Quack, 2005, on 'reciprocity-based' professional networks.) 
Start-ups in therapeutic biotechnology in Silicon Valley resemble professional project networks in many respects (Whitley, 2007: 14). Such firms are often owner managed either by the original entrepreneurs and founders or, more commonly, by private-equity investors who have bought a stake in the company with a view to selling it on in an initial public offering (IPO). These companies are often heavily constrained by key groups of employees, such as researchers, as it is they who underpin the company's ability to come up with new treatments before rivals that, once protected by patents, will be the source of profits for the firm. As this group of workers have advanced knowledge and skills, managers must be willing to share authority with them in meaningful ways across a number of areas. For instance, researchers must be able to use their discretion to decide which experiments to conduct in the future. This, in turn, may have wide-ranging implications for the use of the company's physical and material resources that may prevent the firm from conducting alternative projects.

However, the longevity and scope of organizational careers is likely to be low: if rivals beat the company to a new therapeutic treatment, the organization may cease to exist or managers may decide to make researchers redundant (Casper, 2007). Similarly, if a different approach to the development of a new drug looks more promising than the firm's current techniques, the company may decide to make researchers redundant if that new approach requires a different set of hard-to-learn skills.

\section{Compartmentalized}

The key feature of compartmentalized business systems is the presence of large companies under a unified ownership structure that can co-ordinate and control activities within production chains and across related sectors that are based on common skills, knowledge and 
capabilities, and that can offer economies of scope and scale (Whitley, 2007: 15-16). Such firms are largely self-sufficient, and do not, on the whole, collaborate with other firms, and employers display little commitment to employees. These crucial features reflect ownership and control structures, as such companies are owned and controlled, in an indirect way, by institutional investors and financial markets (Whitley, 1999: 43; see also, Gospel and Pendleton, 2003). Although these ownership patterns may not be sufficient to lead to the privileging of short-term financial objectives by firms, if they are coupled with a strong market for corporate control - that is, if firms can be acquired or taken over relatively easily then these pressures will be more pronounced (O'Sullivan, 2000; Tylecote and Ramirez, 2006).

Consequently, this pressure to maintain or increase short-term profitability limits the commitments that senior managers can make to both lower-level employees and other organizations, including suppliers and rival firms in the same industry (Dyer and Nobeoka, 2000; Lane, 1989). In the case of employees, senior managers may decide that the most appropriate way to surmount any looming profitability problems is to make workers redundant (Gospel and Pendleton, 2003). Thus, many employees will lack the opportunity to extend their skills across a range of the firm's activities (Harcourt and Wood, 2007). Indeed, employers will be cautious about not only sharing significant authority with employees, but also granting them discretion across a range of the company's activities. If they were to share authority with employees, the organization and senior managers would, in part, become dependent on those employees, and, hence, constrained by them. This would, in turn, make dismissing such employees more difficult. The key resources in isolated hierarchies are, therefore, likely to be embodied within a senior tier of managers. 
The consequences of this approach to the management of employees for the firm's capabilities are, firstly, that the ability of the organization to learn will be confined to managers, as they are the ones who have the discretion and knowledge of the company's business activities. Secondly, as most employees do not contribute significantly to the competitiveness of isolated hierarchies, the firm is not dependent upon, or constrained by them. Therefore, managers will be able to reconfigure the organization relatively easily. Finally, because a defining characteristic of isolated hierarchies is their 'self-reliance', they will be able to orchestrate a number of activities, potentially across a number of related sectors. In other words, they will possess considerable co-ordinating capabilities (Whitley, 2010: 463-465).

However, the incentives of employees to their time and effort in developing cross-functional and cross-divisional skills will be low. Consequently, attempts to implement competition strategies based on incremental innovation will be severely limited in isolated hierarchies. Indeed, employees in such firms are likely to have strong incentives to increase their specialist skills, as the commitment to them by the firm is low. They need, therefore, to ensure that they have employment opportunities with other companies. It is only relatively senior managers in such companies who are likely to have deep commitment to the company. However, the ownership structure of such companies can limit the length of employment of senior managers.

It should also be noted, though, that the compartmentalized business system, arguably, affords companies greater room for manoeuvre than other systems. As a result, managers may seek to introduce forms of 'welfare capitalism' (Jacoby, 1997) into the company; this aimed to grant employees a status within the firm, and to protect them, to a certain extent, 
from commercial risks. In concrete terms, US firms that pursued a policy of welfare capitalism introduced health-care schemes and training programmes for employees. However, the types of firms that were able to implement such policies successfully were those that were sheltered from short-term financial pressures either by family ownership or by the separation of ownership and control (Jacoby, 1997).

\section{Centralized Hierarchy}

Centralized hierarchies are associated with state-organized business systems, which are, in turn, linked with environments in which the state is prevalent in economic decision making, and exerts a powerful influence over intermediary organizations. For instance, in such business systems unions are either weak or controlled by the state. As a consequence, wage bargaining, if it is conducted in any meaningful way, is likely to be de-centralized. The reluctance of such states to forbear the presence of unions is likely to be extended to business associations if these act as an impediment to the state's direction of the economy (Whitley, 2007: 43). Indeed, individual companies will be heavily dependent on state agencies and officials in such states, which are likely to control in a direct way access to funding, permits to operate in certain markets, and the use of crucial resources. A corollary of these characteristics is that centralized, hierarchical firms, which operate in such states, will not grant much discretion to employees. Relatedly, employers will see few advantages in offering employees long and extensive careers. Similarly, long-term commitments to business partners or competitors will be difficult to establish, as firms' cardinal relationships are with the state and its agencies rather than other companies (Whitley, 1999: 61-62; Whitley, 2007: 43). Indeed, centralized hierarchies are likely to remain under the control of founding families even if shares are owned by institutional investors. This is, perhaps, most clearly illustrated by the appointment (or attempted appointment) of family members to senior management 
positions within Samsung. Samsung is a listed company, but it is, through crossshareholdings, a family-controlled one.

In terms of capabilities, centralized hierarchies are, as an extension of the ability of the state to direct economic activities, likely to have considerable co-ordinating capabilities. Similarly, such firms are likely to possess significant reconfigurational capabilities if this is required by the state. This latter capability also reflects centralized hierarchies' ability to take decisions free from any constraints imposed by employees, except top managers. Centralized hierarchies' independence from most employees will mean their capability to learn as an organization will be minimal. Indeed, any organizational learning that does take place is likely to be confined to senior managers.

Employment relations within Hyundai Motor Company, which forms part of Hyundai, one of South Korea's oldest and largest family-owned conglomerates or chaebol, closely resemble those outlined within the ideal type of a centralized hierarchy. For instance, the company used the dormitory system to enable workers to be closely supervised and controlled (Cho, 1999, cited in Lansbury et al., 2006). This indicates that little authority was shared with employees. Research by Lansbury et al. (2006: 138) reveals that, despite Hyundai Motor Company adopting certain employment practices in its South Korean facilities from Mitsubishi Motor Company, the firm did not involve its employees in some aspects of decision making at the plant level, maintained high-status differentials between workers and managers at the plant level, and did not enable shop-floor employees to be promoted to higher positions within the plant. This reinforces the idea that little authority sharing occurs within the company. It also indicates that organizational careers are limited in scope for nonmanagerial employees. 
These aspects conform to the ideal type of centralized hierarchy outlined above. Although Lansbury et al. (2006) did not examine organizational performance, other evidence indicates that South Korean companies have found it easier to reach the same productivity levels as local competitors in sectors in which crucial knowledge is explicit rather than tacit, and in which knowledge is embodied in machinery or equipment (Jung and Lee, 2010). This, too, is consistent with the above framework, as organizational learning is likely to be limited to top managers in centralized hierarchies. Lower levels employees do not contribute to organizational learning. As a result, the ability to generate new knowledge to improve existing products or create new ones is limited. However, the success of South Korean firms in the mobile-phone industry, to which they were relative late-comers, suggest that their ability to co-ordinate different capabilities across different economic activities is considerable (Hu and Hsu, 2008).

Although there are, clearly, many differences between South Korea and Russia, the term centralized hierarchy can be applied to companies in Russia, too. In general, employers are free to determine the style of employment relations within companies (Croucher and Cotton, 2009). This often results in a lack of trust between managers and employees (Domsch and Lidokhover, 2007). In addition, the longevity and scope of organizational careers has decreased (Linz and Semykina, 2008). These conditions suggest that organizational learning in Russian companies will be confined to senior managers. Indeed, evidence from Dixon et al. (2007) indicates that those Russian oil companies that they analysed and that exhibited these characteristics had weak organizational learning capabilities in the areas of exploitation and exploration. In addition, and in contrast to South Korean companies, the Russian firms 
that conformed relatively closely to the centralized hierarchy ideal type also lacked extensive co-ordinating capabilities.

\section{Collaborative Hierarchy}

Collaborative hierarchies develop in collaborative and highly co-ordinated business systems, which are characterized by institutional supports for co-operation between collective economic actors. These institutional supports can, inter alia, be provided by the state, which

plays a co-ordinating, but not directive role in the economy. In order to achieve this, the state may encourage the development of intermediary bodies to play a role in the formulation and implementation of (para-)public policies (Whitley, 1999: 62). The significant role played by banks, as opposed to stock markets, in providing credit to companies also facilitates this cooperation, as banks are often closely connected to their debtors, and they cannot easily withdraw their funding if market conditions change. This results, to a certain extent, in the success of banks and their debtor companies becoming intertwined (Whitley, 1999: 62). Therefore, the owners of companies are committed to them, and will not sell their stakes if short-term difficulties are encountered, as institutional investors are likely to do.

Partly as a result of this commitment to firms by their owners, managers are able to adopt a longer-term approach to the business. Consequently, employers will be able to share authority with employees in terms of both depth and breadth, as the pressures to reduce staffing levels as a result of a downturn in profits will be less than they are in companies owned by a number of institutional investors. In addition, employees who form part of the core workforce will be less wary about investing in firm-specific skills, as the company will be under less pressure to make workers redundant in response to decreases in profitability. In other words, the length of job tenures will be increased, and this will enable companies to create a 
workforce with firm-specific skills. This, in turn, will mean that internal labour markets will be important, and any vacant positions within the firm are likely to be filled by existing employees. A corollary of these factors is that collaborative hierarchies will be constrained by their employees.

In terms of organizational capabilities, collaborative hierarchies will possess strong coordinating abilities, as employees are encouraged to develop firm-specific skills, and employees, especially those in highly co-ordinated business systems, are moved between departments; this gives them greater insights into the firm's various functions and division. Hence, co-ordination should be easier to achieve (Whitley, 2010: 466). The emphasis on firm-specific skills and internal labour markets within collaborative hierarchies will mean that they will have considerable organizational learning capabilities, as, firstly, credible employment commitments will lessen workers' concerns about sharing knowledge, and, secondly, employees will have strong incentives to deepen their firm-specific knowledge to improve their career prospects. However, radical reconfigurational capabilities are likely to be severely hindered precisely because of these commitments (Whitley, 2010).

Germany is, perhaps, the archetypal collaborative business system. Despite the increase in the presence of foreign institutional investors on the German stock market, such investors are far less prevalent than they are in the UK, as Table 2 shows. Moreover, this change in the ownership profiles of large German firms has not heralded an emphasis on shareholder value in company decision making (Börsch, 2007). Many shares in German companies are held by non-financial firms; this indicates a degree of cross-shareholding amongst German companies. Such owners can be expected to be committed, and so will not sell their stakes in another company if profits in that other company decline. It is also worth noting that the data 
on stock-market capitalization as a percentage of gross domestic product indicates that the stock market, and, hence, institutional investors play a much greater role in financing companies' activities in the UK than they do in Germany.

XXX

TABLE 2 ABOUT HERE

XXX

The ownership characteristics of many German companies enable them to adopt a long-term perspective on the development of the company. This has been complemented by labourmarket institutions, such as works councils and sectoral collective agreements, which, although not as widespread as they once were, and although sometimes functioning in ways that run counter to archetypical ones (Brewster et al., 2007; Hassel, 1999; Streeck and Hassel, 2003), still play an important role in many German firms (Allen, 2006). These institutional factors have, in general, created co-operative employment relations in German companies (Haake, 2002; Streeck, 1992). Indeed, these institutional factors do not just lead to collaborative employment relations, but can also promote other outcomes that are likely to be beneficial to firms that rely on a relatively high proportion of the company's workforce for their competitiveness. For instance, works councils and collective wage agreements have also been found to be associated with fewer difficulties recruiting, and retaining employees; lower levels of absenteeism; and reduced quit rates (Allen, 2006).

These outcomes strongly suggest that firms are in a position to build upon their employees' commitments to increase their firm-specific skills. Such skills are likely to be of particular value in sectors that are characterized by relatively limited competence destruction risks. This 
could be because products are improved incrementally, and knowledge is cumulative; that is, new knowledge builds upon existing knowledge. For instance, in the automobile sector, product improvements in general require, inter alia, production employees who, firstly, have a deep understanding of how their activities fit into the rest of the manufacturing process, and, secondly, put forward suggestions to improve productivity, and the quality and variety of the finished vehicles (Crouch et al., 2009). In the enterprise-software sector, products are customized to the client firm's demands. In order to compete in this sector, firms must be able to draw on the skills and knowledge of employees who, firstly, have a strong understanding of the firm's products, and, secondly, can comprehend, and cater to client firms' evolving demands. In other words, employees have firm-specific knowledge that must be upgraded in an incremental fashion to improve the firm's service to customers (Casper and Whitley, 2004).

In the latter sector, Casper and Whitley (2004) have shown that sectoral collective wage bargaining, which eases employees' fears over possible exploitation by employers if they have firm-specific skills that severely limit their ability to change employers; corporate governance regulations that grant employee representatives a say in major decisions within large companies; employment-protection legislation that hinders dismissals; and works councillors within individual establishments who must be consulted on matters relating to work organization have led to co-operative workplace employment relations. This has, in turn, created the conditions under which investments in cumulative, firm-specific knowledge can be undertaken. As a result, Casper and Whitley (2004) find that German companies are more competitive in the enterprise-software sector than their UK rivals are. 
In the automobile sector, Jürgens (2008) has argued that the institutions of the archetypal 'German model', such as sectoral collective agreements, works councils, and the vocational training system, have helped German companies to remain competitive. Although the ways in which these institutions operate have changed since the 1980s as a result of globalization, he finds that these main institutions have continued, and that change within the industry has taken place in a co-operative and collaborative way. (See Crouch et al., 2009 for more on changes within the German automobile sector.)

Japan is, arguably, the paradigmatic example of a highly co-ordinated business system. However, once again, it would be incorrect to argue that all inter-organizational co-operation and firms in Japan closely resemble a highly co-ordinated business system, and collaborative hierarchies, respectively. For instance, small firms that offer limited job guarantees, if any, and that do not develop employees' skills form part of the Japanese manufacturing sector (Whitley, 2005; see also Keizer, 2008). These do not conform to the archetypal Japanese firm, but do complement them (Morgan, 2007b). In addition, foreign institutional investors have, collectively, acquired large stakes in Japan companies. Their aim has often been to promote greater returns to shareholders (Jacoby, 2007; Olcott, 2009). Their success, however, is debatable, as, inter alia, corporate governance regulations and existing business linkages have hindered their efforts (Jackson, 2009; Jacoby, 2007; see also Keizer, 2009).

In common with firms in collaborative business systems, those in highly co-ordinated business systems have committed owners. In kereitsu, or corporate networks that are underpinned by ownership ties, this can take the form of a major shareholding by the bank that forms part of the network as well as stakes held by other firms in the group (Jackson, 2009; Vogel, 2006). This facilitates a long-term perspective amongst senior managers within 
large companies, as the threat of being acquired or taken over is diminished. Consequently, the commitments that managers can give to employees about long-term employment security, as least for the firm's core workforce, are more credible. This, in turn, helps to create the conditions under which employers can devolve considerable discretion in both degree and scope to employees. However, for this to happen, employers must also be sanguine that employees will not 'hold up' the firm; that is, employees will not use their key position within the firm to increase their share of the firm's profits by threatening, for example, to delay or halt production. The presence of enterprise rather than industry unions in Japan encourages employees and their representatives to focus on their own firm's prospects rather than consider industry-wide developments (Whitley, 1999). Similarly, established norms amongst large firms not to poach skilled workers as well the sharing of information on wage rates limit the possibilities and incentives for such workers to change employer (Whitley, 2007: 52; see also Sako and Kotosaka, 2012). This is reinforced by seniority-based pay in large Japanese companies. As a result of these institutional factors, large Japanese companies are constrained to a significant extent by their employees.

This enables them to generate strong co-ordination capabilities of economic activities across the network (Dyer and Nobeoka, 2000; Lam, 2005). They also have considerable organizational learning capabilities. These can be related to the practice within many large Japanese companies of encouraging employees to have several areas of responsibility that may overlap with those of others; this encourages employees to develop a holistic and longterm understanding of the firm's activities and objectives. This contrasts with the situation in many large US companies that adopt a narrower perspective on employees' organizational responsibilities, which leads employees to focus on a restricted range of objectives. This, in turn, hinders organizational learning (Hamel, 1991). 


\section{Internationalization, Business Systems, and Multinational Companies}

As noted above, the heightened internationalization of product, capital, and some labour markets has reduced the homogeneity of national (and sub-national) business systems. It has also opened up, at least theoretically, the possibility that firms - in particular, multinational companies (MNCs) - will be able to develop distinctive capabilities that transcend national borders and that are independent of any particular institutional environment (Whitley, 2010: 479). If MNCs can free themselves from their institutional environments, the business systems framework would be undermined. This issue has been addressed within the business systems literature; it is somewhat downplayed in the Varieties of Capitalism paradigm.

However, it is important to highlight that the effects of internationalization on firms' coordination mechanisms and competitive capabilities are likely to be significant only when important resources are located overseas; overseas subsidiary managers play a major role in decision making and capability development; and domestic policies, including employmentrelated measures, are adapted to, and by, foreign sites (Whitley, 2010: 479-480). In the absence of these, MNCs will, in general, find it difficult to develop transnational capabilities. If they fail to create and maintain such capabilities, MNCs will not differ, as strategic economic actors, to similar, yet purely domestic firms. To be sure, within a single MNC, domestic establishments and foreign locations may have capabilities that enable them to compete successfully within the markets they serve; however, their capabilities will remain separate unless organizational practices and routines are changed within the MNC to encourage transnational organizational learning. Learning within firms is likely to be characterized by the transfer of new ideas, skills, and knowledge from innovating subsidiaries to other parts of the organization (Whitley 2010). 
A corollary of this is that the number of MNCs that develop distinctive transnational competitive capabilities - as opposed to those that rely on a collection of discrete competencies located within national subsidiaries - is likely to be low (Whitley, 1998, 2001, 2010). This is particularly so, as the development of transnational organizational learning is likely to characterized by employees making investments in firm-specific skills. This, in turn, will require employees and the MNCs' business partners to be committed to the creation and enrichment of its cross-border competencies.

A number of implications for MNCs' employment relations follow from this. Firstly, the creating employee commitment across the organization will require authority to be shared with those employees. Employees in different locations will need to be able to make important decisions as well as contribute to others within the firm. Secondly, employee commitment for senior managers across the MNC is likely to depend upon them being offered the credible prospect of organizational careers if they contribute significantly to organizational learning. In other words, very senior positions within the firm should not be the preserve of those from the MNC's home country (Whitley, 2010).

As noted above, the willingness of owners and employers to grant decision-making powers to lower level employees and to provide organizational careers will be shaped significantly by institutions. Consequently, the ability of subsidiaries of an MNC that are based in varying types of institutional setting to share authority with employees will differ as will their ability to offer organizational careers (Whitley, 2010). Indeed, even MNCs from countries, such as Japan, that have been able to offer credible long-term employment commitments to their core workforce may find it difficult to operate in the same way abroad (see much of the evidence 
cited in Morgan et al., 2003). Thus, Japanese manufacturing subsidiaries in the UK were unable to offer long-term employment commitments to British workers (Morgan et al., 2003); this is likely to have reduced their ability to learn from the UK. In addition, MNCs may struggle to adapt organizational routines to foreign locations. For instance, Lam (2003) has found that those subsidiaries of Japanese MNCs that sought to gain access to external sources of knowledge often found it difficult because the firms were centralized and authority was not shared with subsidiary managers. By contrast, US MNCs were able to tap into overseas sources of knowledge to a greater extent. If knowledge and skills in specific areas are becoming increasingly dispersed across the world, the country of origin of the MNC may play an important role in the extent to which the company can draw on foreign competencies and integrate them across the whole of the firm.

\section{Conclusions}

This contribution has put forward evidence to corroborate the links between business systems, firm types, employee relations, and organizational capabilities within the business system framework. However, there are relatively few studies that attempt to detail the institutional setting of firms; the technological and market risks associated with different subsectors of the economy; the resultant organizational capabilities needed to surmount those challenges; the employment practices and routines required to create, maintain, and develop those competitive competencies; and the ways in which firms' institutional settings helps or hinders companies implement those routines successfully. This is, perhaps, not surprising. However, from a business systems perspective, analyses that focus on, say, the links between firms' institutional settings and employee turnover halt the analysis too early. From a business system perspective, the analysis should be extended to encompass the links between employee turnover as well as the ability, or otherwise, of firms to compete in their relevant 
product markets. Similarly, those analyses that, for example, examine the links between organizational routines, such as the ways in which work is organized and careers are structured, and organizational capabilities should be deepened so that they incorporate the influence of institutions on the ability of firms to pursue certain routines, and, hence, their ability to compete successfully.

To be sure, this is no easy task. Recent developments in the international economy will make it even more arduous. The internationalization of product, capital and some labour markets means that the opportunities that firms have to overcome domestic institutional constraints have been increased. However, the ability of companies to draw on these institutional resources is likely to depend on the nature of those resources, including their 'transferability'. Thus, some sources of finance may be able to companies in many more locations than was previously the case: Kazakhmys, a Kazakh mining company, is, for instance, listed on the London Stock Exchange, potentially making its owners a dispersed group of investors. By contrast, certain forms of knowledge may be embedded within public science systems, which may hamper the ability of foreign companies to gain access to that knowledge (Allen and Whitley, 2012). Thus, the internationalization of certain markets means that firms institutional settings must be specified rather than inferred from any macro-level framework. As Kazakhmys illustrates, the company may have a more dispersed ownership structure, and be subject to UK regulations on publicly quoted companies, but it is still embedded within the Kazakh business system, as some of its most influential owners and many of its senior managers are Kazakh and its main assets are there. Employment relations are, therefore, likely to be shaped most strongly by the Kazakh employment system. 
In addition to the increasing internationalization of certain institutional resources, some countries have seen heightened institutional diversity at the sub-national level. For instance, the UK has witnessed moves to devolve certain policy-making responsibilities to Scotland, Northern Ireland, and Wales. Consequently, institutions, such as public funding related to industrial policies, have become increasingly varied (Allen and Whitley, 2012). Thus, diversity has increased even within states that may have once been regarded as offering a homogeneous institutional setting to companies. This requires researchers to take heterogeneity into account in their analyses.

This enhanced diversity in the institutional settings of firms that has been wrought by increasing internationalization and heightened sub-national variation also draws attention to the role of actors. In particular, it highlights the ways in which they can select institutional resources to enhance their competitive positions. This, in turn, has implications for the our understanding of the perceptions of collective actors, such as firms, employers' associations, and unions, in the process of institutional displacement, layering, conversion, and drift (Streeck and Thelen, 2005). This implies that institutions are not static, but are subject to contestation by a range of actors with varying levels of autonomy (See, for example, Kristensen and Zeitlin, 2005; Mahoney and Thelen, 2010; Morgan, 2007b). These issues are ones that are likely to be at the heart of analyses that draw on the business systems framework in the future. By doing so, future studies will extend a framework that has already provided key insights into the systematic variation in firms, their priorities, their capabilities, and their levels of competitiveness across a range of countries.

\section{References}


Allen, M.M.C. (2004), ‘The Varieties of Capitalism Paradigm: Not Enough Variety?', SocioEconomic Review, 2(1), 87-107.

Allen, M.M.C. (2006), The Varieties of Capitalism Paradigm: Explaining Germany's Comparative Advantage?, London: Palgrave Macmillan.

Allen, M.M.C. and Aldred, M.L. (2011), 'Varieties of Capitalism, Governance, and HighTech Export Performance: A Fuzzy-Set Analysis of the New EU Member States', Employee Relations 33(4): 334-355.

Allen, M.M.C. and Whitley, R. (2012), 'Internationalization and Sectoral Diversity: The Roles of Organizational Capabilities and Dominant Institutions in Structuring Firms' Responses to Semiglobalization', in Christel Lane and Geoffrey T. Wood (eds), Capitalist Diversity and Diversity within Capitalism, London: Routledge, pp. 97-120.

Allen, M.M.C., Tüselmann, H.-J. and Aldred, M.L. (2011), 'Institutional Frameworks and Radical Innovation: an Analysis of High- and Medium-High-Technology Industries in Germany', International Journal of Public Policy 7, (4, 5, 6): 265-281.

Almond, P. (2011), 'The Sub-National Embeddedness of International HRM', Human Relations, 64(4): 531-551.

Becker-Ritterspach, F., Saka-Helmhout, A. and Hotho, J.J. (2010). 'Practice Transfer in MNEs as the Socially-Embedded Translation of Practices', Critical Perspectives on International Business, 6(1): 8-37.

Bohle, D. and Greskovits, B. (2007), 'The State, Internationalization, and Capitalist Diversity in Eastern Europe', Competition and Change, 11(2): 89-115.

Börsch, A. (2007), Global Pressure, National System: How German Corporate Governance is Changing, Ithaca, NY: Cornell University Press. 
Brewster, C., Croucher, R., Wood, G. and Brookes, M. (2007), 'Collective and Individual Voice: Convergence in Europe?', International Journal of Human Resource Management, 18(7): 1246-1262.

Casper, S. (2007), Creating Silicon Valley in Europe: Public Policies towards New Technology Industries, Oxford: Oxford University Press.

Casper, S. (2009) 'Can New Technology Firms Succeed in Coordinated Market Economies? A Response to Herrmann and Lange', Socio-Economic Review, 7(2): 209-15.

Casper, S. and Whitley, R. (2004) 'Managing Competences in Entrepreneurial Technology Firms: a Comparative Institutional Analysis of Germany, Sweden and the UK', Research Policy, 33(1): 89-106.

Cho, H. J. (1999), 'The Employment Adjustment of Hyundai Motor Company: a Research Focus on Corporate-Level Labour Relations', Korean Journal of Labour Studies, 5(1): 63-96.

Crouch, C. (2005), Capitalist Diversity and Change: Recombinant Governance and Institutional Entrepreneurs, Oxford: Oxford University Press.

Crouch, C., Schröder, M. and Voelzkow, H. (2009), 'Regional and Sectoral Varieties of Capitalism', Economy and Society, 38(4): 654-678.

Crouch, C., Streeck, W., Boyer, R., Amable, B., Hall, P.A. and Jackson, J. (2005), Dialogue on Institutional Complementarity and Political Economy', Socio-Economic Review, 3(2): 359-382.

Crouch, C. and Voelzkow, H. (eds) (2009), Innovation in Local Economies: Germany in Comparative Context, Oxford: Oxford University Press.

Croucher, R. and Cotton, E. (2009), Global Unions, Global Business, London: Middlesex University Press. 
Croucher, R., Wood, G., Brewster, C. and Brookes, M. (forthcoming), 'Employee Turnover, HRM and Institutional Contexts', Economic and Industrial Democracy.

Czaban, L., Hocevar, M., Jaklic, M., and Whitley, R. (2003), 'Path Dependence and Contractual Relations in Emergent Capitalism: Contrasting State Socialist Legacies and Inter-Firm Cooperation in Hungary and Slovenia', Organization Studies, 24(1): 7-28.

Dixon, S.E.A., Meyer, K.E. and Day, M. (2007), 'Exploitation and Exploration Learning and the Development of Organizational Capabilities: a Cross-Case Analysis of the Russian Oil Industry', Human Relations, 60(10): 1493-523.

Djelic, M.-L. and Quack, S. (eds) (2003), Globalization and Institutions: Redefining the Rules of the Economic Game, Cheltenham: Edward Elgar.

Domsch, M. and Lidokhover, T. (2007), 'Introduction: the Broader Historical, Social and Economic Context of the Current Situation in Russia', in M. Domsch and T. Lidokhover (eds), Human Resource Management in Russia, Aldershot: Ashgate.

Dosi, G., Nelson, R. and Winter, S. (eds) (2000), The Nature and Dynamics of Organizational Capabilities, Oxford: Oxford University Press.

Dyer, J.H. and Nobeoka, K. (2000), 'Creating and Managing a High-Performance Knowledge-Sharing Network: The Toyota Case', Strategic Management Journal, 21(3): 345-367.

Fajana, S. (2008), 'The Nigerian Informal Economy: Instigating Decent Work and Pay, and National Development through Unionisation', Employee Relations, 30(4): 372-390

Farrell, H. and Holten, A.-L. (2004), 'Collective Goods in the Local Economy: The Packaging Machinery Cluster in Bologna,' in Colin Crouch, Patrick Le Galès, Carlo Trigilia and Helmut Voelzkow (eds) Local Production Systems in Europe: Reconstruction and Innovation, Oxford: Oxford University Press, pp. 23-45. 
Federation of European Stock Exchanges (FESSE) (2008), Share Ownership Structure in Europe, http://www.bourse.lu/contenu/docs/commun/societe/Actualites/2008/FESE_SHARE_O WNERSHIP_SURVEY_2007.pdf.

Gospel, H. and Pendleton, A. (2003), 'Finance, Corporate Governance and the Management of Labour: A Conceptual and Comparative Analysis', British Journal of Industrial Relations, 41(3): 557-582.

Goyer, M. (2006), 'Varieties of Institutional Investors and National Models of Capitalism: The Transformation of Corporate Governance in France and Germany', Politics and Society, 34(3): 399-430.

Goyer, M. (2011), Contingent Capital: Short-term Institutional Investors and the Evolution of Corporate Governance in France and Germany, Oxford: Oxford University Press.

Haake, S. (2002) 'National Business Systems and Industry-specific Competitiveness', Organization Studies 23(5): 711-36.

Hamel, G. (1991), 'Competition for Competence and Inter-Partner Learning within International Strategic Alliances', Strategic Management Journal, 12(2) 83-103.

Hancké, B., Rhodes, M. and Thatcher, M. (2007), Beyond Varieties of Capitalism: Conflict, Contradictions, and Complementarities in the European Economy, Oxford: Oxford University Press.

Harcourt, M. and Wood, G. (2007) 'The Importance of Employment Protection for Skill Development in Coordinated Market Economies', European Journal of Industrial Relations, 13(2): 141-59.

Hassel, A. (1999), 'The Erosion of the German System of Industrial Relations', British Journal of Industrial Relations, 37(3): 483-505. 
Hu, J.-L. and Hsu, Y.-H. (2008), 'The More Interactive, the More Innovative? A Case Study of South Korean Cellular Phone Manufacturers', Technovation, 28(1, 2): 75-87.

Jackson, G. (2009), 'The Japanese Firm and its Diversity', Economy and Society, 38(3): 605628.

Jacoby, S.M. (1997), Modern Manors: Welfare Capitalism since the New Deal. Princeton: Princeton University Press.

Jacoby, S.M. (2007), 'Principles and Agents: CalPERS and Corporate Governance in Japan', Corporate Governance, 15(1): 1-15.

Jung, M. and Lee, K. (2010), 'Sectoral Systems of Innovation and Productivity Catch-Up: Determinants of the Productivity Gap between Korean and Japanese Firms', Industrial and Corporate Change, 19(4): 1037-1069.

Jürgens, U. (2008), 'Gobalization and Employment Relations in the German Auto Industry', in R. Blanpain and R.D. Lansbury (eds), Globalization and Employment Relations in the Auto Assembly Industry, Alphen: Kluwer Law International, pp. 49-72.

Keizer, A.B. (2008), 'Non-Regular Employment in Japan: Continued and Renewed Dualities', Work, Employment and Society, 22(3): 407-425.

Keizer, A.B. (2009), 'Transformations in- and outside the Internal Labour Market: Institutional Change and Continuity in Japanese Employment Practices', International Journal of Human Resource Management, 20(7): 1521-1535.

Kristensen, P.H. (2006), 'Business Systems in the Age of the "New Economy": Denmark Facing the Challenge in J.L. Campbell, J.A. Hall and O.K. Pedersen (eds), National Identity and the Varieties of Capitalism: The Danish Experience, Montreal: McGillQueen's University Press, pp. 295-320.

Kristensen, P.H. (2011), 'Developing Comprehensive, Enabling Welfare States for Offensive Experimentalist Business Practices' in P.H. Kristensen and K. Lilja (eds), Nordic 
Capitalisms and Globalization: New Forms of Economic Organization and Welfare Institutions, Oxford: Oxford University Press, pp. 220-258.

Kristensen, P.H. and Zeitlin, J. (2005), Local Players in Global Games: The Strategic Constitution of a Multinational Corporation, Oxford: Oxford University Press.

Lam A. (2003), 'Organizational Learning in Multinationals: R\&D Networks of Japanese and US MNEs in the UK', Journal of Management Studies, 40(3): 673-703.

Lam A. (2005), 'Work Roles and Careers of R\&D Scientists in Network Organisations', Industrial Relations, 44(2): 242-275.

Lane, C. (1989), Management and Labour in Europe, Cheltenham: Elgar.

Lane, C. and Wood, G.T. (eds) (2012), Capitalist Diversity and Diversity within Capitalism, London: Routledge.

Lane, D. and Myant, M. (eds) (2007), Varieties of Capitalism in Post-Communist Countries, Palgrave Macmillan, London.

Lange, K. (2009) 'Institutional Embeddedness and the Strategic Leeway of Actors: The Case of the German Therapeutical Biotech Industry', Socio-Economic Review, 7(2): 181207.

Lansbury, R.D., Kwon, S.-H. and Suh, C.-S. (2006), 'Globalization and Employment Relations in the Korean Auto Industry: The Case of the Hyundai Motor Company in Korea, Canada and India, Asia Pacific Business Review, 12(2): 131-147.

Linz, S. and Semykina, A. (2008), 'How Do Workers Fare during Transition? Perceptions of Job Insecurity among Russian Workers, 1995-2004', Labour Economics, 15(3): 442458.

Lundvall, B.-Å. and Lorenz, E. (2006) 'Welfare Systems and National Systems of Innovation', in E. Lorenz and B.-Å. Lundvall (eds), How Europe's Economies Learn: Coordinating Competing Models, Oxford: Oxford University Press, pp. 411-32. 
Mahoney, J. and Thelen, K. (eds) (2010), Explaining Institutional Change: Ambiguity, Agency, and Power, Cambridge: Cambridge University Press.

Malerba, F. (2002), ‘Sectoral Systems of Innovation and Production', Research Policy, 31 (2): $247-264$.

Malerba, F., and Orsenigo, L. (1997), 'Technological Regimes and Sectoral Patterns of Innovative Activities', Industrial and Corporate Change, 6(1): 83-117.

Morgan, G. (2007a), 'National Business Systems Research: Progress and Prospects', Scandinavian Journal of Management, 23(2): 127-145.

Morgan, G. (2007b), 'The Theory of Comparative Capitalisms and the Possibilities for Local Variation', European Review, 15(3): 353-371.

Morgan, G.and Kubo, I. (2005), 'Beyond Path Dependency? Constructing New Models for Institutional Change: The Case of Capital Markets in Japan', Socio-Economic Review, 3(1): 55-82.

Morgan, G. and Quack, S. (2005), 'Internationalization and Capability Development in Professional Services Firms' in G. Morgan, R. Whitley and E. Moen (eds), Changing Capitalisms? Internationalization, Institutional Change, and Systems of Economic Organization, Oxford: Oxford University Press.

Nielsen, P. and Lundvall, B.-Å. (2006) 'Learning Organizations and Industrial Relations: How the Danish Economy Learns', in E. Lorenz and B.-Å. Lundvall (eds), How Europe's Economies Learn: Coordinating Competing Models, Oxford: Oxford University Press, pp. 161-77.

Nölke, A. and Vliegenthart, A. (2009), 'Enlarging the Varieties of Capitalism: the Emergence of Dependent Market Economies in East Central Europe', World Politics, 61(4): 670702. 
O’Sullivan, M. (2000), Contests for Corporate Control: Corporate Governance and Economic Performance in the United States and Germany, Oxford: Oxford University Press.

Olcott, G. (2009), Conflict and Change: Foreign Ownership and the Japanese Firm, Cambridge: Cambridge University Press.

Penrose, E. (1959), The Theory of the Growth of the Firm, Oxford: Blackwell.

Porter, M.E. (1979), 'How Competitive Forces Shape Strategy', Harvard Business Review, 57(2): 137-145.

Sako, M. and Jackson, G. (2006) 'Strategy Meets Institutions: The Transformation of Management-Labor Relations at Deutsche Telekom and NTT.' Industrial and Labor Relations Review, 59(3): 347-366.

Sako, M. and Kotosaka, M. (2012), 'Institutional Change and Organizational Diversity in Japan', in C. Lane and G.T. Wood (eds), Capitalist Diversity and Diversity within Capitalism, London: Routledge, pp. 69-96.

Schneiberg, M. (2007), 'What's on the Path? Path Dependence, Organizational Diversity, and the Problem of Institutional Change in the US Economy, 1900-1950', Socio-Economic Review, 5(1): 47-80.

Simon, H. (2007), Hidden Champions des 21. Jahrhunderts: Die Erfolgstrategien unbekannter Weltmarktführer, Frankfurt a. M.: Campus Verlag.

Streeck, W. (1992), Social Institutions and Economic Performance: Studies of Industrial Relations in Advanced Capitalist Economies. New York: Sage.

Streeck, W. (2009), Re-Forming Capitalism: Institutional Change in the German Political Economy, Oxford: Oxford University Press.

Streeck, W. and Hassel, A. (2003), 'The Crumbling Pillars of Social Partnership', West European Politics, 26(4): 101-124. 
Streeck, W. and Thelen, K. (2005), 'Introduction: Institutional Change in Advanced Political Economies', in W. Streeck and K. Thelen (eds), Beyond Continuity: Institutional Change in Advanced Political Economies, Oxford: Oxford University Press, pp. 1-39. Teece D.J., Pisano, G. and Shuen, A. (1997), 'Dynamic Capabilities and Strategic Management', Strategic Management Journal, 18(7): 509-533.

Tylecote, A. and Ramirez, P. (2006), 'Corporate Governance and Innovation: The UK Compared with the US and “Insider" Economies', Research Policy, 35(1): 160-180 Vogel, S.K. (2006), Japan Remodeled: How Government and Industry are Reforming Japanese Capitalism, Ithaca, NY: Cornell University Press.

Whitley, R. (1990), 'Eastern Asian Enterprise Structures and the Comparative Analysis of Forms of Business Organization', Organization Studies, 11(1): 47-74.

Whitley, R. (1992a), Business Systems in East Asia: Firms, Markets and Societies, London: Sage.

Whitley, R. (ed.) (1992b), European Business Systems: Firms and Markets in their National Contexts, London: Sage.

Whitley, R. (1994), 'Dominant Forms of Economic Organization in Market Economies’, Organization Studies, 15(2): 153-82

Whitley, R. (1999), Divergent Capitalisms: The Social Structuring and Change of Business Systems, Oxford: Oxford University Press.

Whitley, R. (2000), 'The Institutional Structuring of Innovation Strategies: Business Systems, Firm Types and Patterns of Technical Change in Different Market Economies', Organization Studies, 21(5), 855-886.

Whitley, R. (2003), 'From the Search for Universal Correlations to the Institutional Structuring of Economic Organization and Change', Organization, 10(3): 481-502. 
Whitley, R. (2005), 'How National Are Business Systems? The Role of States and Complementary Institutions in Standardizing Systems of Economic Co-ordination and Control at the National Level', In G. Morgan, R. Whitley and E. Moen (Eds) Changing Capitalisms? Internationalization, Institutional Change and Systems of Economic Organization, Oxford: Oxford University Press, pp. 190-231.

Whitley, R. (2007), Business Systems and Organizational Capabilities: The institutional Structuring of Competitive Competences, Oxford: Oxford University Press.

Whitley, R. (2009), 'U.S. Capitalism: A Tarnished Model?', Academy of Management Perspectives, 23(2): 11-22

Whitley, R. (2010), ‘The Institutional Construction of Firms’ in G. Morgan, J.L. Campbell, C. Crouch, O.K. Pedersen and R. Whitley (eds), The Oxford Handbook of Comparative Institutional Analysis, Oxford: Oxford University Press, pp. 453-495.

Whitley, R. and Czaban, L. (1998), 'Institutional Transformation and Enterprise Change in an Emergent Capitalist Economy: The Case of Hungary', Organization Studies, 19(2): 259-280.

Whitley, R. and Morgan, G. (2012), 'Capitalisms and Capitalism in the Twenty-First Century: Introduction' in G. Morgan and R. Whitley (eds), Capitalisms and Capitalism in the Twenty-First Century, Oxford: Oxford University Press, pp. 1-10.

Wilkinson, A. and Fay, C. (2011), 'New Times for Employee Voice?', Human Resource Management, 50(1): 65-74.

Wilkinson, A. and Wood, G. (2012), 'Institutions and Employment Relations: The State of the Art', Industrial Relations, 51 (S1): 373-388.

Williamson, O. E. (1985), The Economic Institutions of Capitalism, New York: The Free Press. 
Wood, G. and Frynas, G. (2006), 'The Institutional Basis of Economic Failure: Anatomy of the Segmented Business System', Socio-Economic Review, 4(2): 239-77.

Wood, G., Croucher, R., Brewster, C., Collings, D.G. and Brookes, M. (2009), 'Varieties of Firm: Complementarity and Bounded Diversity', Journal of Economic Issues, 43(1): 239-258.

Wood, G., Dibben, P., Stride, C. and Webster, E. (2011) 'HRM in Mozambique: Homogenization, Path Dependence or Segmented Business System?', Journal of World Business, 46(1): 31-41. 
Table 1 Ideal Firm Types, and Associated Business Systems, Employment Relations, and Organizational Capabilities

\begin{tabular}{|c|c|c|c|c|c|}
\hline & Opportunistic & $\begin{array}{l}\text { Specialized } \\
\text { network }\end{array}$ & $\begin{array}{l}\text { Type of Firm } \\
\text { Isolated hierarchy }\end{array}$ & $\begin{array}{l}\text { Centralized } \\
\text { hierarchy }\end{array}$ & $\begin{array}{c}\text { Collaborative } \\
\text { hierarchy }\end{array}$ \\
\hline $\begin{array}{l}\text { Business system } \\
\text { associated with }\end{array}$ & Fragmented & $\begin{array}{l}\text { Co-ordinated } \\
\text { industrial } \\
\text { districts, and } \\
\text { project } \\
\text { networks }\end{array}$ & Compartmentalized & $\begin{array}{l}\text { State } \\
\text { organized }\end{array}$ & $\begin{array}{l}\text { Collaborative } \\
\text { and highly co- } \\
\text { ordinated }\end{array}$ \\
\hline Examples & $\begin{array}{l}\text { Informal } \\
\text { economy in } \\
\text { Nigeria }\end{array}$ & $\begin{array}{l}\text { Emilia- } \\
\text { Romagna, } \\
\text { Italy; Baden- } \\
\text { Württemberg, } \\
\text { Germany; } \\
\text { Silicon Valley, } \\
\text { US. }\end{array}$ & US, and UK & $\begin{array}{l}\text { South Korea } \\
\text { before c. } 1990\end{array}$ & $\begin{array}{l}\text { Germany, and } \\
\text { Japan }\end{array}$ \\
\hline $\begin{array}{l}\text { Characteristics } \\
\text { Owner control } \\
\text { type }\end{array}$ & Direct & Direct/Market & Market & Direct & Committed \\
\hline $\begin{array}{l}\text { Employee } \\
\text { constraint }\end{array}$ & Low & Considerable & $\begin{array}{l}\text { Limited to } \\
\text { managers }\end{array}$ & $\begin{array}{l}\text { Limited to top } \\
\text { managers }\end{array}$ & Considerable \\
\hline $\begin{array}{l}\text { Degree of } \\
\text { authority sharing }\end{array}$ & Low & Considerable & Some & Limited & Considerable \\
\hline $\begin{array}{l}\text { Scope of } \\
\text { authority sharing }\end{array}$ & Low & Considerable & $\begin{array}{l}\text { Limited to } \\
\text { managers }\end{array}$ & Limited & Considerable \\
\hline $\begin{array}{l}\text { Longevity and } \\
\text { scope of } \\
\text { organizational } \\
\text { careers } \\
\text { Capabilities }\end{array}$ & Low & Low & Some for managers & Limited & Considerable \\
\hline $\begin{array}{l}\text { Strength of co- } \\
\text { ordinating } \\
\text { capabilities }\end{array}$ & $\begin{array}{l}\text { Restricted to } \\
\text { personal } \\
\text { control }\end{array}$ & $\begin{array}{l}\text { Restricted to } \\
\text { specialized } \\
\text { firms and } \\
\text { limited in } \\
\text { scope }\end{array}$ & Considerable & Considerable & High \\
\hline $\begin{array}{l}\text { Strength of } \\
\text { organizational } \\
\text { learning } \\
\text { capabilities }\end{array}$ & Limited & $\begin{array}{l}\text { Limited to } \\
\text { teams }\end{array}$ & $\begin{array}{l}\text { Limited to } \\
\text { managers }\end{array}$ & $\begin{array}{l}\text { Limited to top } \\
\text { managers }\end{array}$ & Considerable \\
\hline $\begin{array}{l}\text { Strength of } \\
\text { reconfigurational } \\
\text { capabilities }\end{array}$ & $\begin{array}{l}\text { High for } \\
\text { entrepreneurs }\end{array}$ & $\begin{array}{l}\text { Limited in } \\
\text { industrial } \\
\text { districts; high } \\
\text { in professional } \\
\text { project } \\
\text { networks }\end{array}$ & Considerable & Considerable & Limited \\
\hline
\end{tabular}

Source: adapted from Whitley (2010: 463; $c f$. Whitley, 1999: 75) 
Table 2 Stock Market Capitalization, and Stock Ownership Distribution in Germany and the UK, Selected Years 1992-2007

\begin{tabular}{|c|c|c|c|c|}
\hline \multirow{2}{*}{$\begin{array}{l}\text { Country } \\
\text { GERMANY }\end{array}$} & \multicolumn{4}{|c|}{ Year } \\
\hline & 2007 & 2002 & 1997 & 1992 \\
\hline Stock market capitalization (\% GDP) & 63.5 & 34.3 & 38.2 & 16.9 \\
\hline \multicolumn{5}{|l|}{ SHARE OWNERSHIP } \\
\hline Foreign investors & 21.3 & 14.8 & 10.1 & 10.4 \\
\hline Domestic investors & 78.7 & 85.2 & 89.9 & 89.6 \\
\hline \multicolumn{5}{|l|}{ Comprising: } \\
\hline Private financial enterprises & 24.2 & 31.5 & 29.8 & 23.3 \\
\hline Private non-financial companies/orgs & 39.3 & 36.6 & 37.6 & 42.2 \\
\hline Individual investors/households & 13.3 & 14.0 & 17.3 & 18.8 \\
\hline Public sector & 1.9 & 3.1 & 5.2 & 5.3 \\
\hline Not identified & 0.0 & 0.0 & 0.0 & 0.0 \\
\hline UK & 2006 & 2002 & 1997 & 1992 \\
\hline Stock market capitalization (\% GDP) & 157.9 & 117.8 & 149.4 & 85.9 \\
\hline \multicolumn{5}{|l|}{ SHARE OWNERSHIP } \\
\hline Foreign investors & 40.0 & 35.9 & 28.0 & 13.1 \\
\hline Domestic investors & 60.0 & 64.1 & 72.2 & 86.9 \\
\hline \multicolumn{5}{|l|}{ Comprising: } \\
\hline Private financial enterprises & 44.4 & 47.8 & 52.5 & 61.1 \\
\hline Private non-financial companies/orgs & 2.7 & 1.9 & 3.1 & 3.6 \\
\hline Individual investors/ households & 12.8 & 14.3 & 16.5 & 20.4 \\
\hline Public sector & 0.1 & 0.1 & 0.1 & 1.8 \\
\hline Not identified & & 0.0 & 0.0 & 0.0 \\
\hline
\end{tabular}

Notes: The years vary slightly for Germany and the UK; this reflects the availability of the FESE (2008) data; rounding errors may prevent appropriate figures equalling 100 per cent.

Sources: Stock market capitalization: World Development Indicators (Edition: September 2009); all other values: Federation of European Stock Exchanges (2008). 